\title{
Partial Molar Volume of 18-Crown-6 Complex Ions with Alkali-Metal Ions in Methanol
}

\author{
Hiromitsu HIRAKAWA* and Alfredo MAESTRE ${ }^{\dagger}$ \\ Received August 12, 1996 ; Accepted January 6, 1997
}

\begin{abstract}
The sedimentation potential (SP), molar conductivities and partial molar volumes at infinite dilution of salts $(\mathrm{NaCl}, \mathrm{KCl}$ and $\mathrm{CsCl})$ in methanol containing 18 -Crown-6 (18 C 6) have been measured. By combining SP, transference numbers and lirniting partial molar volumes of salts containing $18 \mathrm{C} 6$, single-ion volumes at infinite dilution of $\left[18 \mathrm{C} 6-\mathrm{Ml}^{+}\right]$complex ion and $\mathrm{Cl}^{-}$ion have been evaluated. The single-ion partial molar volume of chloride ion is in fair agreement with that observed for alkali-metal-salts in methanol not containing $18 \mathrm{C} 6$. This fact suggests clearly that the charge of the alkali-metal ion trapped in the $18 \mathrm{C} 6$ cavity is effectively shielded by $18 \mathrm{C} 6$. The biggest volume change is shown for the $18 \mathrm{C} 6$ complex ion with $\mathrm{K}^{+}$among all the alkali-metal ions studied.
\end{abstract}

\section{INTRODUCTION}

The details about many characteristics of crown ethers have been resvaluated ${ }^{13}$ since its existence was discovered by Pedersen.' It was shown that the most important characteristic is that crown ethers interact with certain cations, especially alkali- and alkaline-earth-metal ions to form stable complexes. ${ }^{3.8}$ These properties have resulted in considerable interest in crown ethers and their applications in solution chemistry. ${ }^{9.13)}$

When a solution of electrolyte is placed in an accelerating field, an electrical signal is produced in the solution as result of differences in the movement of the cation and anion in the applied field. This potential is called the sedimentation potential (SP) ${ }^{14)}$ and up to now has been measured for electrolytes in various solvents. ${ }^{15-17)}$ Nowadays, SP measurements have been demonstrated in order to apply as an ion sensor capable of detecting specific ion by means of 18 -Crown-6 $(18 \mathrm{C} 6)$ as a crown ethers. ${ }^{18)}$ That is to say, the SP of alkalimetal salts $(\mathrm{NaCl}, \mathrm{KCl}$ and $\mathrm{CsCl})$ in various solvents containing $18 \mathrm{C} 6$ has been detected with SP measuring apparatus. ${ }^{18)}$ As the results, the significant differences between SP of alkali-metal salts in methanol containing $18 \mathrm{C} 6$ and that in methanol Kagoshima University, Faculty of Engineering (1-21-40 Kagoshima-shi 890, Japan)

${ }^{\dagger}$ Universidad de Sevilla, Facultad de Quimica Fisica (41012 Sevilla, Spain)

Key Words: Sedimentation Potential, Limiting Molar Conductivity, Partial Molar Volume, 18-Crown-6 not containing $18 \mathrm{C} 6$ are observed. That is due to the complex formation between $18 \mathrm{C} 6$ and the alkali-metal ions. From a viewpoint of solution chemistry, it is so interesting to study the factors influencing complex formation between $18 \mathrm{C} 6$ and alkali-metal ions and the behavior of the $18 \mathrm{C} 6$ complex ions in methanol, respectively. By the way, SP is the only physical quantity capable of dividing the partial molar volume of an electrolyte into its ionic constituents without relying on any kind of extrathermodynamic or semiempirical relationship. To divide the partial molar volume of an electrolyte, such as the $18 \mathrm{C} 6$ complexes with alkali-metal ions, $\left[18 \mathrm{C} 6-\mathrm{M}^{+}\right] \mathrm{Cl}$, into its constituent ions by means of SP, we need to know the transference number of the $18 \mathrm{C} 6$ complex ions, [18 C 6-M $\mathrm{M}^{+}$, and the partial molar volume of $18 \mathrm{C} 6$ complexes, $V_{2}^{\infty}\left(\left[18 \mathrm{C} 6-\mathrm{M}^{+}\right] \mathrm{Cl}\right)$, at the infinite dilution.

In this work, in order to obtain the information about solvation behavior of $\left[18 \mathrm{C} 6-\mathrm{M}^{+}\right]$in methanol, SP of alkali-metal salts in methanol containing $18 \mathrm{C} 6$ is measured. Secondly, the limiting conductivities of alkali-metal salts in methanol containing $18 \mathrm{C} 6$ is determined in order to calculate the corresponding transference number for the $18 \mathrm{C} 6$ complex ions. In this case, it is assumed that the association between the $18 \mathrm{C} 6$ complex ion and chloride ion is negligible and $18 \mathrm{C} 6$ forms $1: 1$ complexes with alkali-metal ions. Thirdly, the partial molar volume of the $18 \mathrm{C} 6$ complexes with alkalimetal ions by the density measurement is 
determined. From SP, the transference number and the partial molar volume of the $18 \mathrm{C} 6$ complexes with alkali-metal ions obtained at above, the partial molar volume of the $18 \mathrm{C} 6$ complexes with alkalimetal ions is divided into the single-ion partial molar volumes of the $18 \mathrm{C} 6$ complex ions and that of the chloride ion. In addition, the results obtained from this experiments will be evaluated with electron spectroscopy for chemical analysis (ESCA). On the basis of the results obtained, the behavior of the $18 \mathrm{C} 6$ complex ions and chloride ion in methanol will be discussed in details.

\section{EXPERIMENTAL PROCEDURE}

\subsection{Reagents}

18 C 6 (Aldrich, stated purity 99.5\%) was kept in an evacuated desiccator and was used with no further purification. Methanol (Merck, stated purity $99.8 \%$, water content $0.005 \%$ ) was kept over a thermally activated $3 \mathrm{~A}$ molecular sieve prior to use. Alkali-metal salts $(\mathrm{NaCl}, \mathrm{KCl}$ and $\mathrm{CsCl}$ ) purchased from Wako Junyaku (99.5\%) and were dried for three days at $393 \mathrm{~K}$ in a vacuum oven. All reagents were kept in a vacuum desiccator with $\mathrm{P}_{2} \mathrm{O}_{5}$.

\subsection{SP measurements}

SP of alkali-metal salts $(\mathrm{MCl})$ in methanol containing $18 \mathrm{C} 6(0.05 \mathrm{M})$ was measured at $298 \mathrm{~K}$ at the acceleration of $5.0 \mathrm{G}$ using the same apparatus and procedure as reported previously. ${ }^{16-18)}$

\subsection{Conductivity measurements}

Resistance measurements were carried out using a Beckman model RC-18 A conductivity bridge at a frequency of $1 \mathrm{kHz}$. Two Jones type conductivity cells with cell constants $0.4883 \pm 0.001$ $\mathrm{cm}^{-1}$ and $0.7689 \pm 0.001 \mathrm{~cm}^{-1}$ were calibrated with aqueous $\mathrm{KCl}$ solutions as recommended previously. An oil thermostat maintained the temperature at $298.15 \pm 0.003 \mathrm{~K}$. Temperature control was monitored at $\pm 0.001 \mathrm{~K}$ near the cell with a platinum resistance probe connected to an ASL model F 250 thermometer, which was calibrated by Isotech (England). The whole system was placed in a room in which the temperature was kept constant within $\pm 0.5 \mathrm{~K}$. Various solution of $\mathrm{MCl}$ in methanol containing $18 \mathrm{C} 6$ were prepared by weighting and added to cells where their resistance was measured. For all values of specific conductivi- ty, $K_{0}$, that corresponding to the solvent was subtracted.

\subsection{Density measurements}

The densities to obtain the limiting partial molar volumes of $18 \mathrm{C} 6(0.05 \mathrm{M})$ complexes with alkali-metal salts were also measured at $298.15 \mathrm{~K}$ with a vibrating-tube densitometer (A. Paar, model DMA $60 / 602$ ) of $8 \times 10^{-6} \mathrm{~g} \cdot \mathrm{cm}^{-3}$.

\section{RESULTS AND DISCUSSION}

\section{1 SP of alkali-metal salts}

If a significant difference exists in the effective volume of a cation and an anion in solution, the responses of cation and anion to an externally applied accelerating field should be different. This difference in the motion of dissolved ions lead to an appearance of an electric potential, known as the sedimentation potential (SP). If the partial molar volume and the transference number of an electrolyte are available, the partial molar volume of the electrolyte can be divided into cationic and anionic parts by means of SP data. For that purpose, variation of SP (O) with concentration of alkali-metal salts in methanol containing $18 \mathrm{C} 6$ $(0.05 \mathrm{M})$ is compared with those $(\cdots)$ of not containing $18 \mathrm{C} 6$ in Fig. 1. As is shown in Fig. 1, the absolute numerical values of SP are small at high salt concentration, approaching a certain value at about $0.001 \mathrm{M}$. This limiting value is generally referred to as the SP. The significant differences between SP $(\mathbf{O})$ of alkali-metal salts in methanol containing $18 \mathrm{C} 6$ and those $(\cdots)$ of not containing $18 \mathrm{C} 6$ are observed in Fig. 1. This fact can be explained as follows. $18 \mathrm{C} 6$ traps alkali-

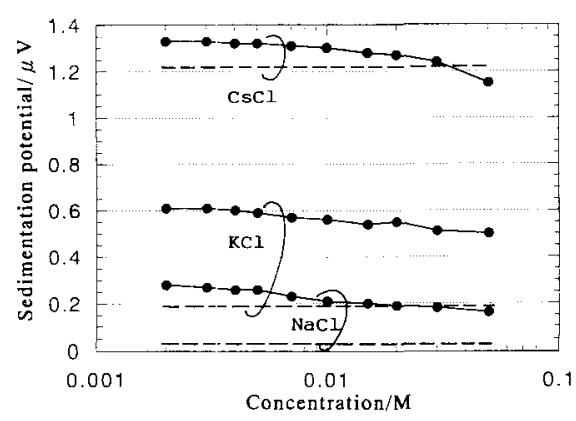

Fig. 1 Sedimentation potential of alkali-metal salts in methanol containing $18 \mathrm{C} 6(\mathrm{O})$ and that not containing $18 \mathrm{C} 6(\cdots)$. 
metal ion in its cavity and forms the $18 \mathrm{C} 6$ complexes with alkali-metal ions, $\left[18{\left.\mathrm{C} 6-\mathrm{M}^{+}\right] \mathrm{Cl}}\right.$ $\left(\mathrm{M}^{+}\right.$is $\mathrm{Na}^{+}, \mathrm{K}^{+}, \mathrm{Cs}^{+}$, respectively). At that case, the complex formation constant, $\log \mathrm{K}_{\mathrm{ML}}{ }^{+}$, between $18 \mathrm{C} 6$ and alkali-metal ions in methanol is 4.32 , 6.10 and 4.62 for $\mathrm{Na}^{+}, \mathrm{K}^{+}$and $\mathrm{Cs}^{+}$, respectively. ${ }^{19}$ Therefore, when alkali-metal salts, $\mathrm{MCl}$, is dissolved in methanol containing $18 \mathrm{C} 6$, the ratio of the $18 \mathrm{C} 6$ complexes with alkali-metal ions, $\left[18 \mathrm{C}^{-}-\mathrm{M}^{+}\right]$ $\mathrm{Cl}$, which occupy in the solution is about 100 percent. ${ }^{19)}$ Consequently, SP (O) of alkali-metal salts in methanol containing $18 \mathrm{C} 6$ is equal to measure that of $\left[18 \mathrm{C} 6-\mathrm{M}^{+}\right] \mathrm{Cl}$ in methanol. While, SP in alkali-metal salts $(\cdots)$ in methanol not containing $18 \mathrm{C} 6$ is equal to measure that of $\mathrm{MCl}$ in methanol. SP is generally proportional to the difference in molecular weight between cation and anion in the solvent. ${ }^{14-16)}$ The anion of both compounds are the same. The molecular weight of $\left[18 \mathrm{C} 6-\mathrm{M}^{+}\right]$is higher than that of $\mathrm{M}^{+}$. Therefore, a big differences between SP ( $O$ ) for the complexed state and that $(\cdots)$ of uncomplexed state are observed. Among all the alkali-metal salts studied, $\mathrm{KCl}$ shows the biggest difference of SP. This is a consequence of having the highest complex formation constant. ${ }^{19)}$

\section{2 Conductivity of $18 \mathrm{C} 6$ complexes}

In analyzing the conductivity data for $18 \mathrm{C} 6$ complexes, however, it is assumed that the association between a cation and anion is negligible under these highly dilute experimental conditions and that $18 \mathrm{C} 6$ forms $1: 1$ complexes with alkalimetal ions in this work. The equilibrium equation is given by : ${ }^{20)}$

$$
\begin{aligned}
& \mathbf{M}^{+}+\mathrm{Cl}^{-}+\mathrm{L} \rightleftharpoons \mathrm{MCl}+[\mathrm{ML}] \mathrm{Cl} \\
& \Lambda_{\text {Total }}=\alpha \Lambda([\mathrm{ML}] \mathrm{Cl})+(1-\alpha) \Lambda([\mathrm{ML}]) \mathrm{Cl}
\end{aligned}
$$

where $\mathrm{L}$ stands for $18 \mathrm{C} 6$ and $\mathrm{M}$ is either $\mathrm{Na}, \mathrm{K}$, or Cs. $\alpha$ is the fraction of free alkali-metal ions that are not in the complexed state. $\Lambda_{\text {Total }}$ is the total molar conductivity when alkali-metal salts are dissolved in methanol containing $18 \mathrm{C} 6$. $\Lambda([\mathbf{M C l}])$ and $\Lambda([\mathbf{M L}] \mathbf{C l})$ represent the conductivity of the alkali-metal salts and that of the complex. $\Lambda_{\text {Total }}$ is obtained from the resistance measured with the conductivity bridge and the cell constant. $\alpha$ can be obtained from the complex

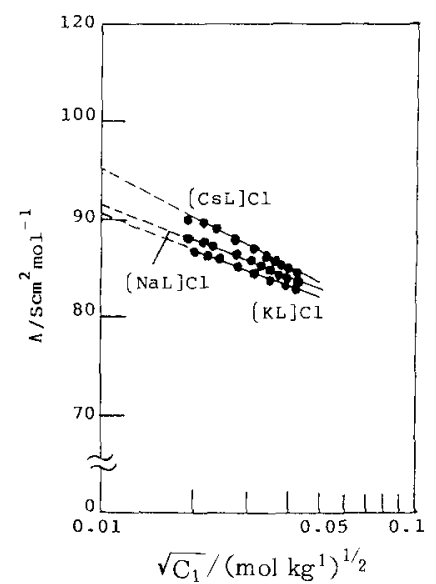

Fig. 2 Molar conductivity, $\Lambda([\mathrm{MCl}] \mathrm{Cl})$ as function of concentration $\sqrt{\mathrm{C}_{1}}$ for $[\mathrm{ML}] \mathrm{Cl}$.

formation constant, $\mathrm{K}_{\mathrm{ML}}{ }^{+}$, which is defined as, ${ }^{203}$

$$
\mathbf{K}_{\mathbf{M L}}+=\frac{\left[\mathbf{M L}^{+}\right]}{\left[\mathbf{M}^{+}\right][\mathbf{L}]}=\frac{[1-\alpha]}{\alpha[\mathrm{L}]}
$$

The corresponding values of $\Lambda([\mathrm{MCl}])^{17,21)}$ and $\mathrm{K}_{\mathrm{ML}}{ }^{+19)}$ in methanol have been taken from the literature. Therefore, the molar conductivities of complex $[\mathrm{ML}] \mathrm{Cl}, \Lambda([\mathrm{MCl}] \mathrm{Cl})$, can be calculated from equation (1). A plot of $\Lambda([\mathrm{MCl}] \mathrm{Cl})$ vs. $[\mathrm{MLCl}]^{1 / 2}$ is shown in Fig. 2. The value of $\Lambda([\mathrm{MCl}] \mathrm{Cl})$ at infinite dilution, $\Lambda^{\infty}([\mathrm{ML}] \mathrm{Cl})$ was calculated by extrapolation using a leastsquares fit. The results obtained are given below.

$$
\begin{aligned}
& \Lambda^{\infty}([\mathrm{NaL}] \mathrm{Cl}) / \mathrm{S} \mathrm{cm}^{2} \mathrm{~mol}^{-1}=92.85 \pm 0.19, \\
& \Lambda^{\infty}([\mathrm{KL}] \mathrm{Cl}) / \mathrm{S} \mathrm{cm}^{2} \mathrm{~mol}^{-1}=92.42 \pm 0.21, \\
& \Lambda^{\infty}([\mathrm{CsL}] \mathrm{Cl}) / \mathrm{S} \mathrm{cm}^{2} \mathrm{~mol}^{-1}=95.49 \pm 0.11
\end{aligned}
$$

Since we have known the value of the ionic molar conductivity at infinite dilution for chloride ion in methanol, ${ }^{21)}$ the corresponding values for complex ions $\mathrm{ML}^{+}$can be determined :

$\Lambda^{\infty}\left(\mathrm{NaL}^{+}\right)=40.49 / \mathrm{S} \mathrm{cm}^{2} \mathrm{~mol}^{-1} ; \Lambda^{\infty}\left(\mathrm{KL}^{+}\right)=$

$40.06 / \mathrm{S} \mathrm{cm}^{2} \mathrm{~mol}^{-1} ; \Lambda^{\infty}\left(\mathrm{CsL}^{+}\right)=43.13 / \mathrm{S} \mathrm{cm}^{2} \mathrm{~mol}^{-1}$ The value for $\Lambda^{\infty}\left(\mathrm{KL}^{+}\right)$is in agreement with that of Takeda, ${ }^{21)} 39.9 / \mathrm{S} \mathrm{cm}^{2} \mathrm{~mol}^{-1}$. Moreover, the transference numbers, $t_{+}$and $t_{-}$for complex ion and chloride ion are calculated by using the following equation.

$$
\mathrm{t}_{+}=\Lambda^{\infty}\left(\mathrm{ML}^{+}\right) / \Lambda^{\infty}([\mathrm{ML}] \mathrm{Cl}), \mathrm{t}_{-}=1-\mathrm{t}_{+}
$$

\subsection{Limiting partial molar volume for $18 \mathrm{C} 6 \mathrm{com}-$ plexes}

In a liquid mixture of methanol, $18 \mathrm{C} 6$ and 
alkali-metal salts $\mathrm{MCl}$, equilibrium equation on molality is expressed as follows. ${ }^{22)}$

$$
\begin{aligned}
& \mathrm{M}^{+}+\mathrm{L}+\mathrm{Cl}^{-} \rightleftharpoons \mathrm{ML}^{+}+\mathrm{Cl}^{-} \\
& \alpha \mathrm{m}_{\mathrm{E}} \mathrm{m}_{\mathrm{L}}-(1-\alpha) \mathrm{m}_{\mathrm{E}} \quad(1-\alpha) \mathrm{m}_{\mathrm{E}}
\end{aligned}
$$

here $\mathbf{M}^{+}, \mathbf{L}$, and $\alpha$ are presented in the above paragraph. $\mathrm{m}$ stands for molality and the subscript $\mathrm{E}$ and $\mathrm{L}$ represent electrolyte and $18 \mathrm{C} 6$, respectively. When alkali-metal salts are dissolved in methanol containing $18 \mathrm{C} 6$, the total apparent molar volume, $V_{\phi}$, can be expressed as follows. ${ }^{22)}$

$$
V_{\phi}=\frac{m_{E} m_{E}+m_{L} m_{L}}{m_{\text {total }} \mathrm{d}}+\frac{10^{3}\left(\mathrm{~d}_{0}-\mathrm{d}\right)}{m_{\text {total }} \mathrm{d}}
$$

Where $m_{E}$ and $m_{L}$ are the molalities of the $\mathrm{MCl}$ and crown ether (L), respectively, $d_{0}$ and $d$ are the densities of the solvent and the solution, respectively. $\mathrm{M}_{\mathrm{E}}$ and $\mathrm{M}_{\mathrm{L}}$ are the molecular weights of $\mathrm{MCl}$ and L. $\mathrm{m}_{\text {total }}$ is $\mathrm{m}_{\mathrm{E}}+\mathrm{m}_{\mathrm{L}}$. The value of $V_{\phi}$ can be calculated by measuring $d$ and $d_{0}$ with the densitometer.

On the other hand, the total apparent molar volumes, $V_{\phi}$, can be expressed in a similar way as those for the conductivity in equation $(1):{ }^{22)}$

$$
\begin{aligned}
& V_{\phi}=\frac{\mathrm{m}_{\mathrm{E}}}{\mathrm{m}_{\text {total }}} \alpha V_{\phi}(\mathrm{E})+\frac{\mathrm{m}_{\mathrm{L}}-\mathrm{m}_{\mathrm{E}}(1-\alpha)}{\mathrm{m}_{\text {total }}} \\
& V_{\phi}(\mathrm{L})+\frac{\mathrm{m}_{\mathrm{E}}}{\mathrm{m}_{\text {total }}}(1-\alpha) V_{\phi}([\mathrm{ML}] \mathrm{Cl})
\end{aligned}
$$

where $V_{\phi}(\mathrm{E}), V_{\phi}(\mathrm{L})$, and $V_{\phi}([\mathrm{ML}] \mathrm{Cl})$ are the partial molar volume of $\mathrm{MCl}, 18 \mathrm{C} 6$, and $18 \mathrm{C} 6$ complex, respectively. From equation (6), $V_{\phi}$ is also represented as follows. ${ }^{22}$

$$
\begin{aligned}
& V_{\phi}=\frac{\mathrm{m}_{\mathrm{E}}}{\mathrm{m}_{\text {total }}} \alpha V_{\phi}(\mathrm{E})+\frac{\mathrm{m}_{\mathrm{L}}-\mathrm{m}_{\mathrm{E}}(1-\alpha)}{\mathrm{m}_{\text {total }}} \\
& V_{\phi}(\mathrm{L})=\frac{\mathrm{m}_{\mathrm{E}}}{\mathrm{m}_{\text {total }}}(1-\alpha)\left[V_{2}^{\infty}([\mathrm{ML}] \mathrm{Cl})\right. \\
& \left.+\mathrm{b}^{\prime} \sqrt{(1-\alpha) \mathrm{m}_{\mathrm{E}}}\right]
\end{aligned}
$$

Where b' are an empirical constant. $V_{2}^{\infty}([\mathrm{ML}] \mathrm{Cl})$ is the partial molar volume of $18 \mathrm{C} 6$ complexes with alkali-metal ions at infinite dilution. Here, $V_{\phi}$ (L) is calculated from density data in the same way as equation (5). And $\alpha$ is calculated from equation (2). The value of $V_{\phi}(\mathrm{E})$ is also reported previously. ${ }^{17)}$

In order to obtain $V_{2}{ }^{\infty}([\mathrm{ML}] \mathrm{Cl})(\mathrm{L}=18 \mathrm{C} 6$, $\mathbf{M}=\mathrm{Na}^{+}, \mathrm{K}^{+}, \mathrm{Cs}^{+}$) from equation (7), $\mathrm{Y}$ and $\mathrm{X}$ are written as equation (8), and then equation (7) is given as follows.

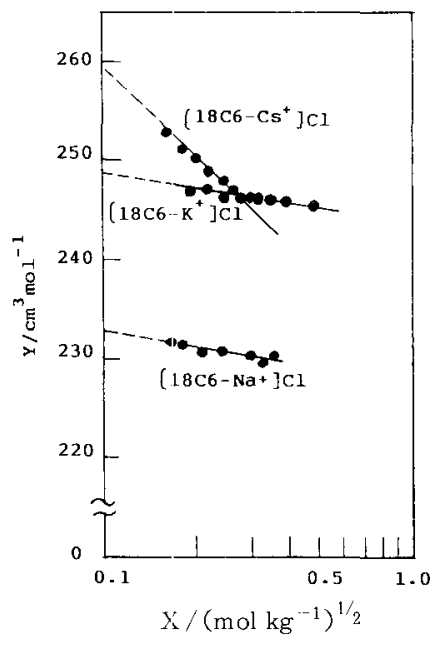

Fig. 3 Partial molar volume, $\mathrm{Y}$ as function of $\mathbf{X}=\sqrt{(1-\alpha) \mathrm{m}_{\mathrm{E}}}$ for morality $\mathrm{m}_{\mathrm{E}}$ of $[\mathrm{MCl}]$.

$$
\begin{aligned}
& Y=\frac{V_{\phi}-\frac{\mathrm{m}_{\mathrm{E}}}{\mathrm{m}_{\text {total }}} \alpha V_{\phi}(\mathrm{E})-\frac{\mathrm{m}_{\mathrm{L}}-\mathrm{m}_{\mathrm{E}}(1-\alpha)}{\mathrm{m}_{\text {total }}} V_{\phi}(\mathrm{L})}{\frac{\mathrm{m}_{\mathrm{E}}}{\mathrm{m}_{\text {total }}}(1-\alpha)} \\
& \mathrm{X}=\sqrt{(1-\alpha) \mathrm{m}_{\mathrm{E}}} \\
& Y=V_{2}^{\infty}+\mathrm{b}^{\prime} X
\end{aligned}
$$

$\mathrm{Y}$ of equation (9) has been plotted as function of $\mathrm{X}$. The result is shown in Fig. 3. As is shown in Fig. 3, the apparent molar volumes of $V_{2}^{\infty}\left(\left[18 \mathrm{C} 6-\mathrm{M}^{+}\right]\right.$ $\mathrm{Cl})$ can be determined by extrapolation of the linear $\mathrm{Y}$ vs. $\mathrm{X}$ plot to the intercept. $V_{2}^{\infty}([18 \mathrm{C} 6$ $\left.\left.\mathrm{M}^{+}\right] \mathrm{Cl}\right) / \mathrm{cm}^{3} \mathrm{~mol}^{-1}$ obtained from Fig. 3 is as follows.

$$
\begin{aligned}
& V_{2}^{\infty}\left(\left[18 \mathrm{C} 6-\mathrm{Na}^{+}\right] \mathrm{Cl}\right)=232.00 \pm 0.4 \\
& V_{2}^{\infty}\left(\left[18 \mathrm{C} 6-\mathrm{K}^{+}\right] \mathrm{Cl}\right)=249.0 \pm 0.5 \\
& V_{2}^{\infty}\left(\left[18 \mathrm{C} 6-\mathrm{Cs}^{+}\right] \mathrm{Cl}\right)=259.5 \pm 0.4
\end{aligned}
$$

\subsection{Ionic partial molar volume}

SP of alkali-metal salts generated in methanol containing $18 \mathrm{C} 6$ using our apparatus is expressed as follows : ${ }^{14-16)}$

$$
\begin{array}{r}
S P=0.005 \times 10^{-6}\left[\mathrm{t}_{+}\left(\mathrm{m}_{+}-V_{+}{ }^{0} \mathrm{~d}_{0}\right)\right. \\
\left.-\mathrm{t}_{-}\left(\mathrm{m}_{-}-V^{0} \mathrm{~d}_{0}\right)\right] \mathrm{x}_{0}
\end{array}
$$

where $\mathrm{t}_{+}, \mathrm{m}_{+}$and $V_{+}{ }^{\circ}$ are the transference number, the molecular weight and the partial molar volume of cation, respectively. Similarly, $\mathrm{t}_{-}, \mathrm{m}_{-}$and $V_{-}{ }^{\circ}$ are these of anion. $d_{0}$ is the density of the solvent, and $\mathrm{x}_{0}$ is the distance between electrodes. Since $V_{2}{ }^{\infty}$ 
$=V_{+}{ }^{\circ}+V_{-}{ }^{\circ}{ }^{1416)}$ by combining the SP measured, the transference number obtained from equation (3) and the partial molar volume obtained, the limiting partial molar volume $V_{2}{ }^{\infty}\left(\left[18 \mathrm{C} 6-\mathrm{M}^{+}\right] \mathrm{Cl}\right)$ has been split into cationic and anionic contributions, $V_{+}{ }^{\circ} / \mathrm{cm}^{3} \mathrm{~mol}^{-1}, V_{-} \% / \mathrm{cm}^{3} \mathrm{~mol}^{-1}$, respectively. The results obtained are shown in Table 1 along with SP values, the transference numbers of $\left[18 \mathrm{C} 6-\mathrm{M}^{+}\right]$ and the partial molar volume $V_{i}^{\infty} / \mathrm{cm}^{3} \mathrm{~mol}^{-1}$ obtained. As is shown in Table 1, the partial molar volumes of the $18 \mathrm{C} 6$-complex ions with alkalimetal ions, $V_{+}{ }^{\circ}\left(\left[18 \mathrm{C} 6-\mathrm{M}^{+}\right]\right)$, increase with increasing molecular weight, while the partial molar volume of chloride ion, $V_{-}{ }^{\circ}\left(\mathrm{Cl}^{-}\right)$, hardly changes. Besides, when the partial molar volume of $V_{+}^{\circ}([18$ C 6-M $\left.\left.\mathrm{M}^{+}\right]\right)$is compared with that of $V_{2}{ }^{\infty}(18 \mathrm{C} 6)$ $\left(223.87 \pm 0.47 / \mathrm{cm}^{3} \mathrm{~mol}^{-1}\right)$ obtained in this work, the change rate of $V_{+}{ }^{\circ}\left(\left[18 \mathrm{C}^{6}-\mathrm{M}^{+}\right]\right)$against the partial molar volume of alkali-metal ions is the biggest for $V_{+}{ }^{\circ}\left(\left[18 \mathrm{C} \mathrm{6-K^{+ }}\right]\right)$ among $V_{+}{ }^{\circ}([18 \mathrm{C} 6-$ $\left.\left.\mathrm{M}^{+}\right]\right)$. On the contrary, $V_{+}{ }^{\circ}\left(\left[18 \mathrm{C} 6-\mathrm{Na}^{+}\right]\right)$is the smallest. Moreover, $\boldsymbol{V}_{-}^{\circ}\left(\mathrm{Cl}^{-}\right)$is in fair agreement with that in methanol not containing $18 \mathrm{C} 6 .{ }^{17)}$ In order to clarify this fact, the intensity of photoelectron from the same solution used in this work was measured with ESCA (Shimazu Co., Ltd., ESCA1000) equipped at Kagoshima Univ. Before measuring the intensity of photoelectron from the solution, the solution of alkali-metal salts (concentration is $0.01 \mathrm{M}$ ) in methanol not containing $18 \mathrm{C} 6$ and those in methanol containing $18 \mathrm{C} 6$ (concentration is $1.0 \mathrm{M}$ ) are dried with an infrared desiccator. The six samples of crystalline thin film are made of the solutions. The intensity of photoelectron against binding energy for the six samples, is measured with ESCA. The intensity of photoelectron of alkali-metal ions from three samples containing $18 \mathrm{C} 6$ arnong six samples shown in Fig. 4 (a)-(c). (a) is $\mathrm{NaCl}$ in methanol containing $18 \mathrm{C} 6$, (b) and (c) are $\mathrm{KCl}$ and $\mathrm{CsCl}$ in the same solvent. Although no results from three samples not containing $18 \mathrm{C} 6$ is shown for want of space, the intensity of photoelectron of alkali-metal ions from three samples containing $18 \mathrm{C} 6$ is much smaller than that of the same ions from three samples not containing $18 \mathrm{C} 6$. Besides, as is shown in Fig. 4 (a)-(c), the intensity of photoelectron from $\mathrm{K}^{+}$ion is the smallest among alkali-metal ions. When rearranging the results mentioned above, the results demonstrate clearly that $18 \mathrm{C} 6$ traps selectively $\mathrm{K}^{+}$ion in its cavity, and the charge of $\mathrm{K}^{+}$ion is effectively shielded by $18 \mathrm{C}^{2} .{ }^{122)}$

\section{CONCLUSIONS}

We have made detailed measurements of conductance and the partial molar volume of the $18 \mathrm{C}$ 6 complexes with alkali-metal ions and SP of alkalimetal salts in methanol containing $18 \mathrm{C} 6$. By combining the transference number, the partial molar volume and SP, single-ion volumes at infinite dilution of the $18 \mathrm{C} 6$ complexes have been obtained. Moreover, intensity of photoelectron from alkalimetal for the same solutions used measurements of SP have been also observed with ESCA. It is clarified that when $18 \mathrm{C} 6$ forms the $18 \mathrm{C} 6$ complexes with alkali-metal ions, the change rate of $V_{+}^{\circ}\left(\left[18 \mathrm{C} 6-\mathrm{M}^{+}\right]\right)$against the partial molar volume of alkali-metal ions is the biggest for $V_{+}{ }^{\circ}\left(\left[18 \mathrm{C} 6-\mathrm{K}^{+}\right]\right)$with $\mathrm{K}^{+}$ion among those studied, while that for $V_{-}^{\circ}\left(\mathrm{Cl}^{-}\right)$hardly changes. This demonstrates clearly that $18 \mathrm{C} 6$-complex formation with $\mathrm{K}^{+}$ion is stronger than that with the other ions, and its charge being effectively shielded by $18 \mathrm{C} 6$.

The authors wish to thank Mr. Y. Oozono and Mr. T. Kakoi of this Univ. for his analysis with ESCA and for making thin film.

Table 1 Ionic partial molar volumes of 18C6-complex ions with alkalimetal and that of chloride ions at $298 \mathrm{~K}$.

\begin{tabular}{|c|c|c|c|c|c|}
\hline$\left[18 \mathrm{C} 6-\mathrm{M}^{+}\right] \mathrm{Cl}$ & $\begin{array}{c}\text { SP } \\
(\mu V)\end{array}$ & $t_{+}$ & $\begin{array}{c}V_{2}{ }^{\infty} \\
\left(\mathrm{cm}^{3} \mathrm{~mol}^{-1}\right)\end{array}$ & $\begin{array}{c}V_{+}{ }^{0} \\
\left(\mathrm{~cm}^{3} \mathrm{~mol}^{-1}\right)\end{array}$ & $\begin{array}{c}V_{-}{ }^{0} \\
\left(\mathrm{~cm}^{3} \mathrm{~mol}^{-1}\right)\end{array}$ \\
\hline$\left[18 \mathrm{C} 6-\mathrm{Na}^{+}\right] \mathrm{Cl}$ & 0.28 & 0.436 & 232.0 & 223.1 & 8.92 \\
\hline$\left[18 \mathrm{C}^{2}-\mathrm{K}^{+}\right] \mathrm{Cl}$ & 0.61 & 0.427 & 249.0 & 239.9 & 9.06 \\
\hline$\left[18 \mathrm{Cb}^{-\mathrm{Cs}^{+}}\right] \mathrm{Cl}$ & 1.33 & 0.452 & 259.5 & 250.5 & 9.05 \\
\hline
\end{tabular}




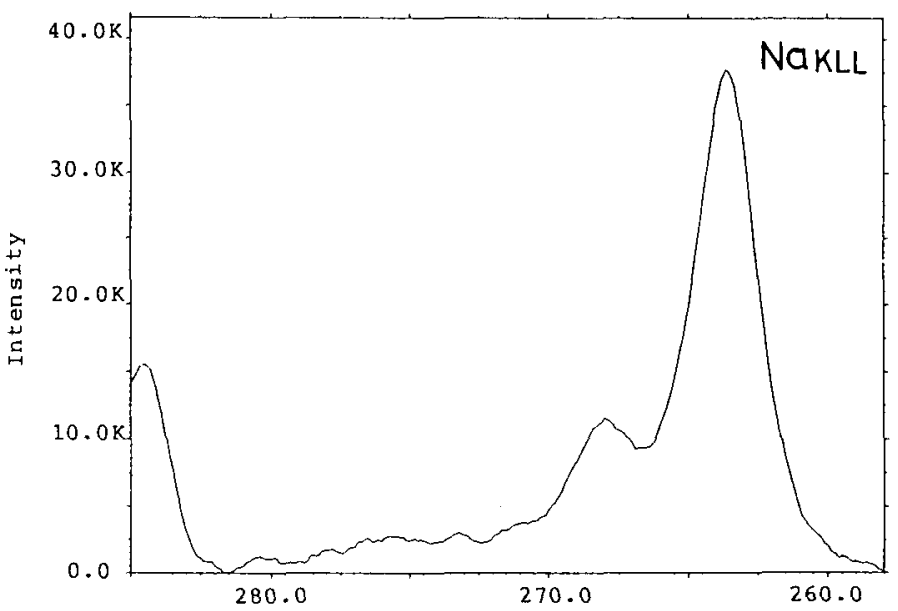

(a) Binding energy(5.0ev/div)
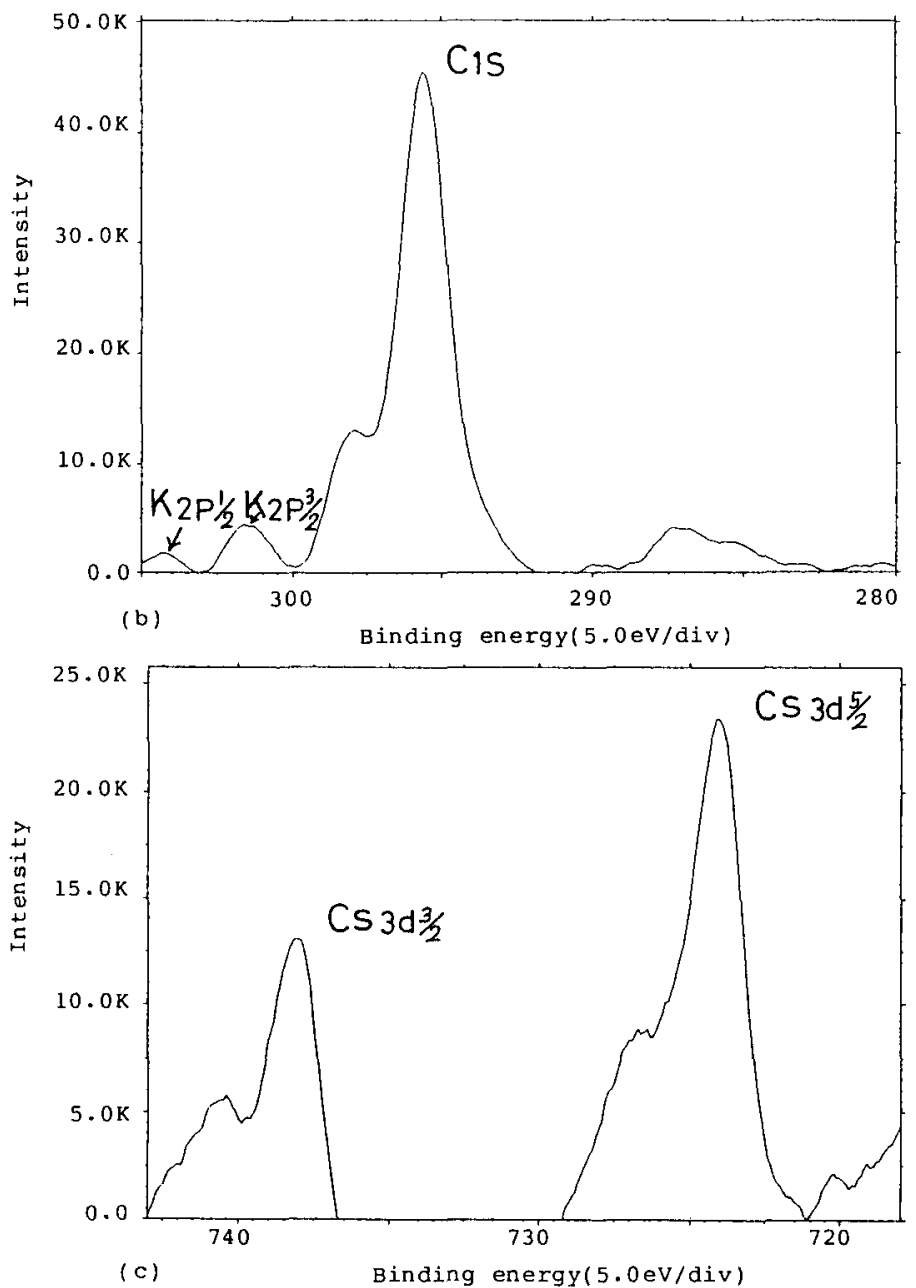

Fig. 4 Photoelectron spectrum of alkali metal from thin film made of alkalimetal salts $(0.01 \mathrm{M})$ in methanol contained $18 \mathrm{C} 6(1.0 \mathrm{M})$. Thin film ; (a) $\mathrm{NaCl}$, (b) $\mathrm{KCl}$, (c) $\mathrm{CsCl}$.

\section{References}

1) R. Oda, T. Syouno, I. Tabuse, Chemistry of Crown Ether, Kagaku Dozin (1976).

2) C. J.Pederson, J.Am. Chem. Soc., 89, 7017 (1967).

3) H. K. Frensdorff, J. Am. Chem. Soc., 93, 600 (1971).

4) C. J. Pederson, Fed. Proc., Fed. Am. Soc. Exp. Biol., 27, 1305 (1968).

5) Y. Takeda and H. Goto, Bull. Chem. Soc. Jpn., 52, 2501 (1979),

6) D.F.Evans, S. L. Welington and E. L. Cussler, J. Solution Chem., 1, 499 (1977).

7) J. J. Christensen, D. J. Eatough and R.M. Izatt, Chem. Rev., 74, 351 (1974).

8) A. C. Knipe, J. Chem. Educ., 53, 618 (1976).

9) E.P.Kyba, M.G.Siegel, L.R.Sousa, G. D. Y. Soga and D. J. Cram, J. Am. Chem. Soc., 95, 2691 (1973).

10) E.P.Kyba, M.G.Siegel, L.R.Sousa, G. D. Y. Soga and D. J. Cram, J. Am. Chem. Soc., 95, 2692 (1973).

11) U. Takaki, T. E. Hogen and J. Smid, J. Am. Chem. Soc., 93, 6760 (1971).

12) S. Kopolow, T.E. Hogen Esch and J. Smid, Macromolecules, 4, 359(1971).

13) G. A. Rechnitz and E. Eyal, Anal. Chem., 44, 370 (1972).

14) R. Zana and E. Yeager, J. Phys. Chem., 71, 521 (1967).

15) H. Hirakawa, F. Kawaizumi and $H$. Nomura, Denki Kagaku, 61, 936 (1993).

16) H. Hirakawa, J. Phys. Chem., 91, 3453 (1987).

17) H. Hirakawa, H. Nomura and F. Kawaizumi, Bull. Chem. Soc. Jpn. 62, 1781 (1989).

18) H. Hirakawa, IEICE, Trans., Japan, J 78-C-II, 437 (1995).

19) Y.Takeda, Bull. Chem. Soc. Jpn., 54, 3133 (1981).

20) Y. Takeda, H. Yano, M. Ishibashi and H. Isozumi, Bull. Chem. Soc Jpn., 53, 72 (1980).

21) Y.Takeda, Bull. Chem. Soc. Jpn., 56, 866 (1983).

22) H. Høiland, J. A. Ringseth and E. Vikingstad, J. Solution Chem., 7, 515 (1978). 